\title{
The Response of Fresh Water Fish Syndontisclarias Juveniles to Varied Zinc Sulphide Concentrations Obtained from the River Benueat Makurdi, Benue State Nigeria
}

\author{
Akaahan Terngu James ${ }^{1 *}$, Olabanji FM² and Azua ET ${ }^{1}$ \\ ${ }^{1}$ Department of Biological Sciences, University of Agriculture, Nigeria \\ ${ }^{2}$ Department of Environmental Biotechnology, National Biotechnology Agency Abuja, \\ Nigeria
}

\section{Research Article \\ Volume 3 Issue 1}

Received Date: January 17, 2018

Published Date: February 01, 2018

*Corresponding author: Akaahan TJA, Environmental Science and Zoology Unit, Department of Biological Sciences, University of Agriculture, P.M.B. 2373 Makurdi Benue state Nigeria, Tel: +2348037737675; E-mail: terngu.adaga@gmail.com

\section{Abstract}

Zinc is one of the heavy metals that is common in the Earth's crust. This metal gets into the environment through manmade and natural ways. In this study, standard solutions of zinc sulphide were prepared and exposed to Synodontisclarias juveniles, A fresh water fish obtained from River Benue at Makurdi during its season in 2017. The standard solutions

were: $0.5,1.0,1.5,2.0$ and $2.5 \mathrm{mg} / \mathrm{L}$ and the exposure period was acute within 96 hours under laboratory condition in the bowls containing 80 litres with 20 individual members in each of the bowl's concentration after the successful climitasation of the fish. Although the metal is nutritional essential at trace concentration in the body of organism of animals but toxic at elevated concentrations, which informed the need for this study and due its abundance in the Earth's crust. The results of the study depict a change in the body colour of the fish, change in its shape, abnormal swimming and death of fish at the exposure to the elevated concentration during the time of the study. The $\mathrm{LC}_{50}$ was recorded at $1.00 \mathrm{mg} / \mathrm{L}$ with the death of half members of the fresh water fish exposed to the toxicant, zinc sulphide for four days study period. However, no death was recorded in the bowl without the toxicant concentration indicating that the death rate was due to the toxic effects of the zinc sulphide to the fish. There was increased in the death of the fish from the lowest to the highest concentration of the zinc sulphide on the fish of 40 and $90 \%$ respectively during the exposure time. Thus, indicating that the higher the concentration of the metal the more toxic it is. This is irrespective of its nutritional value of the metal in the body of organism and can be transferred through food chain with man been the most affected hence the fish is widely consumed by man. There was a strong relationship between the metal and the death of the fish with $\mathrm{R}^{2}$ value of 0.8754 . Consequently, the probit transformed mortality of the toxicant have an $\mathrm{R}^{2}$ value of 0.6562 , while the log transformed concentration death rate with the fish was weak with $\mathrm{R}^{2}$ value of 0.1575 . This may be due to the low values 
of the log transformed metal concentration. The water quality in which the fish were exposed with the toxicant were affected with at varied concentrations with mean values of $4.71 \pm 0.79 \mathrm{mg} / \mathrm{L}, 463.70 \pm 91.93 \mu \mathrm{S} / \mathrm{cm}, 233.33 \pm 35.41 \mathrm{mg} / \mathrm{L}$, $7.46 \pm 0.20$ and $25.08 \pm 0.60{ }^{\circ} \mathrm{C}$ of DO, conductivity, TDS, $\mathrm{pH}$ and water temperature respectively. The t-test at $5 \%$ was significant across all the concentration during the time of exposure of the fish. The study concludes that zinc at elevated concentrations is detrimental to the fish and human health and therefore recommended for routine monitoring of zinc in the aquatic environment due its abundance in the earth's crust and the high risk of washing into the waters sources and taken up by the fish.

Keywords: Zinc sulphide; Synodontisclarias; River Benue; Makurdi; Varied concentration

Abbreviations: FEDRIP: Federal Research Progress Data base; FAO: Food and Agricultural Organisations; IAIA: International Association of Impact Assessment.

\section{Introduction}

Zinc is an element commonly found in the Earth's crust. It is released into the environment from both natural and anthropogenic sources. All the same the zinc releases into the environment from the anthropogenic sources supersedes that of natural sources. The basic or primary anthropogenic sources of zinc metal in the environment (air, water, soil) is due to mining and metallurgic activities, involving the extraction of zinc and the commercial use of zinc products for development [1]. However worldwide, the leaching of zinc to the soil is usually the prevalent source or reservoir of zinc in the environment before it is subsequently washed into the water bodies [1]. Similarly, Rani, et al., reported that the elevated concentration of zinc level in the soils is not only a threat or risk to the soil ecosystem but also affects the water bodies [2]. This is because the zinc is washed or leached into these water bodies either from the point source or non-point source. This is possible because the washing and leaching of pollutants does not recognised boundaries. Although, zinc is an essential trace element in the bodies of organisms, but it is toxic and poisonous in the food and diet at elevated or higher concentrations [3].

In Nigeria, Zinc is plentiful in the soil and covers a $600 \mathrm{~km}$ belt within the Benue trough. It is about $14 \mathrm{~km}$ in the mining district of Eyiaba and its surrounding villages of Ameka, Amori and Ohanakwu. Eboyi state south eastern Nigeria [4]. The activities of biology can facility the mobility of zinc in the aquatic environment or ecosystems. The metal has the ability of bio concentrating moderately in the body of the fish and other aquatic organisms [3]. The bio concentration of the zinc in the tissues and organs of the fish may affect the fish and change its behavioural functions. Consequently, the risk of transferring this metal to the next trophic level is very high due to the fact that fish is the rich source of protein for humans and may accumulate in the organs of humans as well due its bio concentration and result to health challenge in the humans [5]. The maximum concentration of or bio safety consumption of zinc in the organs of fish for consumption as recommended by the Food and Agricultural Organisations, FAO, is $35.00 \mu \mathrm{g} / \mathrm{g}-1$. The concentration above the FAO recommended standard of zinc in the fish diet is toxic and detrimental to the fish its self and humans who eats fish as a rich source of protein material [6].

This study is imperative and indispensable due the high deposit of the zinc in the Earth's crust along the Benue trough and its possibility of washing into the river Benue from leaching and washing by surface run off from zinc waste materials and accumulate in the bodies of the fish cannot be over ruled. Unfortunately, in Nigeria the fish are consumed without checking their health status and integrity, most especially when the demand for the fish far exceeds its supply and the proportion of animal protein that is readily available [7]. This scenario makes Nigerians consume fish without recourse to knowing the health condition of the fish. The Synodontis is one of the cat fish species of commercial value in the abundant population in the fresh water of Northern Nigeria with Makurdi and River at Makurd in Benue state been inclusive. All the same the state of the knowledge on the various cat fish species in Nigeria is due to their gross anatomy and some behavioural characteristics [8]. The Squeaker or upside down cat fish, Synodontisclarias (Linnaeus 1758) is bentho pelagic potamodrous fresh water fish that is found water with a pH range of 6.5-9.5 [9]. This fish is found in good numbers in the fresh water of River Benue and the fish is widely consumed in Makurdi without minding the health integrity of the fish. The aim of this study therefore is to assess and monitor 
the response of the fish exposed to the elevated concentration of zinc to different concentration of the zinc and monitoring the response of the metal to the elevated concentrations on the fish. This is indispensable because this fish species is only obtained from the wild and in this case but it is widely consumed by the people when it is trapped from river Benue. This is based on the rich source of the zinc in the soils of the Benue trough and the high risk of zinc pollution in the surface waters of River Benue and to recommend for the monitoring of the metal in the water body.

\section{Materials and Methods}

\section{Study Area}

The study was carried out in Makurdi Figure 1 and the Syndontisclarias juveniles were obtained from the fisher man. This was done under special arrangement and the fisher men were met with at the Wadata fishing market located on the bank of the river Benue for the collection of the live juveniles of Synodontisclarias as scheduled and arranged with them. Makurdi town is the headquarters of Makurdi Local Government Area and capital of Benue State. The town is located between latitude $7^{\circ} 38^{\prime} \mathrm{N}$ and $7^{\circ} 50^{\prime} \mathrm{N}$, and longitude $8^{\circ} 24^{\prime} \mathrm{E}$ and $8^{\circ} 38^{\prime} \mathrm{E}$. It is situated in the Benue valley in the North Central region of Nigeria. It is traversed by the second largest river in the country, the River Benue. The climate of Makurdi town is the tropical wet and dry type, Koppen's Aw classification, with double maxima [10]. The rainy season lasts from April to October, with 5 months of dry season (November to March). Annual rainfall in Makurdi town is consistently high, with an average annual total of approximately 1173 mm [11]. Temperature in Makurdi is however, generally high throughout the year, with February and March as the hottest months. Temperature in Makurdi varies from a daily of $40^{\circ} \mathrm{C}$ and a minimum of $22.5^{\circ} \mathrm{C}$ [12]. The vegetation of Makurdi town is the guinea savannah. This vegetation type has been adversely affected by human activities leading to the clear-cutting of tree cover in many parts of the town. The river Benue passes through the Makurdi town from Yola Adamawa state to where it meets with the River Niger at Lokoja, Kogi state Nigeria. Fishing activities and sand dredging are the major economic activities in the Benue River within Makurdi metropolitan area. More so, the river is used for getting domestic water supply for Makurdi Water Works to be treated and supply to the residents of Makurdi through Makurdi water works. Other people use the river water directly without adequate treatment. All the same, the river is not devoid from pollution sources as the brewery and rice milling industries are located on the bank of the River. Wastes from the operations of these industrials are discharged into the river without minding its detrimental effects. Indiscriminate dumping of wastes and even defecation is done inside the river among residents in Makurdi that live on the bank of the River. Makurdi town is inhabited by many tribes with a population of 297,398 of out of which 157,295 are males and 140,103 are females [13]. These tribes include the Tivs, Idomas, Etilos, Jukuns, Egede, Hausas, Yorubas and Ibos. The Tivs are the dominant tribe. Makurdi town is made up largely of people who engage in civil service duties, commercial activities and agrarian peasantry. Makurdi town is a builtup area with the highest concentration of people in high level and Wadata. Dense population also exist in some low-lying parts of the town such as Wurukum.

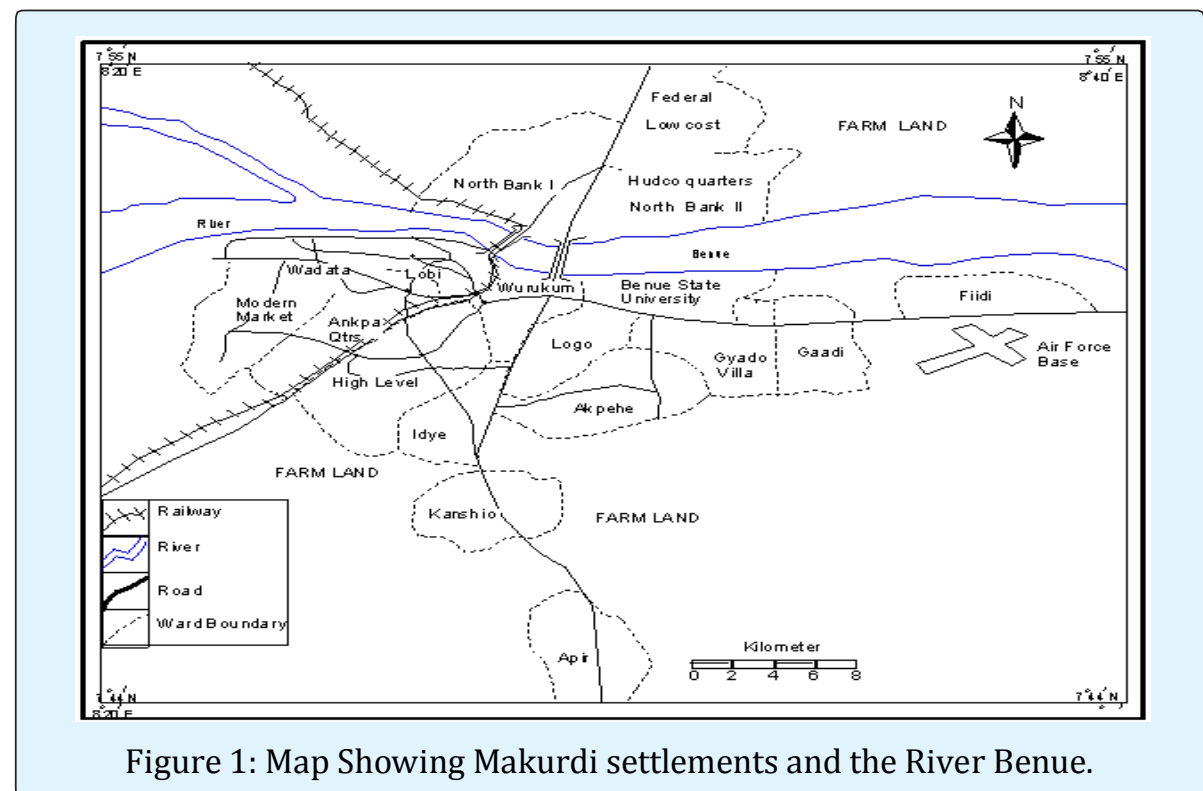

Akaahan Terngu James, et al. The Response of Fresh Water Fish Syndontisclarias Juveniles to Varied Zinc Sulphide Concentrations Obtained from the River Benueat Copyright@ Akaahan Terngu James, et al. Makurdi, Benue State Nigeria. Adv Clin Toxicol 2018, 3(1): 000125. 


\section{Fish Samples Collection of Synodontisclarias}

The juveniles of Synodontisclarias numbering about one hundred and eighty of them were bought from the River Benue at the Wadata fish markets situated on the bank of the river with special arrangements with the fisher men to enable us get live individuals for this study. These fish specimens were carried in the bowls of good sizes to the laboratory of the Fisheries and Aquaculture Department of the Federal University of Agriculture, Makurdi, Benue State, Nigeria for further analysis.

\section{Acclimatization of Syodontisclarias in the Laboratory}

The fish samples of Syondotiscalrias were acclimatized to the laboratory conditions. The fish were fed with artificial feed in the course of the acclimatization in the laboratory for a period of 21 days. The mean body size and weight of the fish samples were $6.6 \mathrm{~cm}$ and $2.3 \mathrm{~g}$ respectively. The same sex of the fish samples was used for the studies. The fish samples were starved for the day that they were collected from the fisher men as the result of stress that may affect fish in the ease of digestion and this may cause death. However, the feeding of the fish samples started the following day in the morning, and the fish samples were given commercial feed diet which was copens of $2 \mathrm{~mm}$ at the initial weight of the body of $4 \%$ of the [14]. Out of the one hundred and eight juveniles of Synodontisclarias that were bought with the fisher men, only, one hundred and twenty of them survived the acclimatization process. Twenty of the individuals of the Synodontisclarias were placed in bowls of 80 litres capacity of water in the course of the acclimatization process and time that lasted for complete 21 days. The water in the bowls containing the fish samples for the studies was changed daily for the 21 days acclimatisation period. This is to prevent the accumulation of wastes from metabolism activities in the bowls that may cause death and disease of the fish samples and avoid contamination of the water in the bowls. Therefore, new water was replaced daily throughout the period of the acclimatization of the Synodontisclarias.

\section{Preparation of Stock and Standard Solution of Zinc Sulphide}

$5.00 \mathrm{~g}$ of zinc sulphide was weighed using laboratory digital weighing balance. The zinc compound was then poured into $1.00 \mathrm{dm}^{3}$ volumetric flask with $500.00 \mathrm{~mL}$ of distilled water. The corked of the volumetric was covered on its mouth and the content was vigorously shaken to enable the powered salts to dissolve into a homogenous solution. There after the distil water was then added to make up the volume to $1.00 \mathrm{dm}^{3}$. The solution was allowed to stand for some time and then filtered with a Whatman filter paper. The residue obtained from the filtrate was then dried in the air for the period of 24 hours and its weight was determined. The weight of the residue was $1.49 \mathrm{~g}$ which shows that only about $3.51 \mathrm{~g}$ of the zinc sulphide salt that was dissolved in the solution. The stock solution was then $3.51 \mathrm{~g} / \mathrm{dm}^{3}$ from where other standard solutions for the studies were determined.

\section{Determination of Lethal Concentration}

The procedures of toxicity trial to determine test concentration were in line with that of FAO [6]. To ascertain the $\mathrm{LC}_{50}$ value during the acute exposure time of 96 hours with reference to FAO [15].

\section{Application of the Zinc sulphide as Toxicant to the Fish juveniles of Synodontisclarias}

The test of toxicity was carried out on active individuals of acclimatized juveniles of Synodontisclarias only. The study was acute and the exposure time was $96 \mathrm{hr}$ and the $\mathrm{LC}_{50}$ of the zinc sulphide concentration of $0.5 \mathrm{mg} / \mathrm{l}, 1.0 \mathrm{mg} / \mathrm{l}, 1.5 \mathrm{mg} / \mathrm{l}, 2.0 \mathrm{mg} / \mathrm{l}$ and $2.5 \mathrm{mg} / \mathrm{l}$ were prepared from the stock solutions and were made and applied to the twenty juveniles of Synodontisclarias placed in different bowls with the concentration written broadly on each the bowls in the laboratory. Another twenty individuals of the active members of the Syondontisclarias that survived were placed in the bowls without the zinc sulphide concentration and they serve as the unexposed devoid of the toxicant which represent the control set up for the acute period of 96 hours test period of the study. The bowls were covered with a mesh to prevent the juveniles from jumping out of the water. The fish that were dead in the course of the study were identified by an absolute lack of movement. The dead individuals of Synodontisclarias were removed immediately from the bowls and as they were detected from the study set up out of the test solution. This was done across all the test set up in the Laboratory during the study time.

\section{Determination of the Physico-Chemical Parameter of Water}

Water quality parameters of TDS, DO, electrical conductivity $\mathrm{pH}$ and water temperature were measured in the laboratory with measuring meters in line with standard methods. Hanna meters were the brand of the meters used for testing the above parameters. 


\section{Data Analysis}

The concentrations of the test studies were changed into the logarithm of base ten and the death rate percentage from each of the toxicant standard solution were transformed into the probit value [16]. The probit values results were plotted against the different concentration of the zinc sulphide test solution. The physico-chemical results were subjected to student $t$ test analysis and descriptive statistics.

\section{Results}

\section{Toxicity of Different Concentration of Zinc sulphide Exposed to Synodontisclarias Juveniles}

The Data in Table 1 is the acute toxicity test for 96 hours of Synodontisclaria juveniles exposed to zinc sulphide during the course of the study. A look at the obtained results show that the highest mortality of 18 (90\%) individuals of Synodontisclarias out of the 20 individuals in the bowls that were exposed to the $2.50 \mathrm{mg} / \mathrm{L}$ concentration of zinc sulphide during study period died and the lowest mortality of $8(40 \%)$ individuals out of 20 individuals of Synodontisclarias that were exposed in the $0.5 \mathrm{mg} / \mathrm{L}$ concentration of the toxicant out of the total $\mathrm{m}$ of 20 individuals exposed to the concentration died. Meanwhile, no death was recorded in the bowls without the zinc sulphide concentration throughout the study period. Nevertheless, half of the individuals (10 individuals of the Synodontisclarias out of the 20 members of the fish exposed to the $1.00 \mathrm{mg} / \mathrm{L}$ of zinc sulphide during the study died. Thus, making the $\mathrm{LC}_{50}$ concentration of the zinc sulphide to be $1.00 \mathrm{mg} / \mathrm{L}$ in the course of the research period. The general trend of the death of the fish in the course of the study was that any increment in the concentration of the toxicant increases the death of the fish exposed to it within the short period of the study. However, the data in Figure 2 is the regression of probit mortality values plotted against the concentration of zinc sulphide exposed to the Synodontisclarias juveniles and the result shows a moderate relationship between the concentrations of zincsulphide and the death of the fish exposed to the fish with the $R^{2}$ value of 0.66 . Figure 3 is the result of the regression of probit values log transformed concentration of zinc sulphide exposed to individuals of Synodontisclarias. The result showed that there is very weak relationship between the log transformed concentration and the mortality of the fish with a $R^{2}$ value of 0.16 . The result in Figure 4 is the regression of percentage mortality values and concentration of zincsulphide exposed to the Synodontisclarias, a fresh water fish. A critical look at the figure depicts that there is a strong correlation between the concentration of the zincsulphide and the mortality of the fish with $\mathrm{R}^{2}$ value of 0.87 .

The result presented in Table 2 is the Water quality characteristics at different concentrations of zinc sulphide. The results showed that mean values of DO. Conductivity, TDS, $\mathrm{pH}$ and temperature were $4.71 \pm 0.79$, $463.40 \pm 91.92,233.33 \pm 35.41,7.46 \pm 0.203$ and $25.08 \pm 0.60$ respectively. The t-test was significant across all the water quality parameters at the different concentrations $(\mathrm{P} \leq 0.05)$ during the study time in all the concentrations that the fish were exposed into.

\begin{tabular}{|c|c|c|c|c|c|c|}
\hline s/n & $\begin{array}{c}\text { Concentra } \\
\text { tion (mg/L) }\end{array}$ & $\begin{array}{c}\text { Log of } \\
\text { concentra } \\
\text { tion }\end{array}$ & $\begin{array}{c}\text { Number o Number } \\
\text { fish } \\
\text { Exposed }\end{array}$ & $\begin{array}{c}\text { of fish } \\
\text { died }\end{array}$ & $\begin{array}{c}\text { Mortality } \\
\text { Value }\end{array}$ \\
\hline 1 & 0 & 0 & 20 & 0 & 0 & 0 \\
\hline 2 & 0.5 & -0.301 & 20 & 8 & 40 & 4.76 \\
\hline 3 & 1 & 0 & 20 & 10 & 50 & 5 \\
\hline 4 & 1.5 & 0.176 & 20 & 14 & 70 & 5.52 \\
\hline 5 & 2 & 0.301 & 20 & 15 & 75 & 5.67 \\
\hline 6 & 2.5 & 0.398 & 20 & 18 & 90 & 6.28 \\
\hline
\end{tabular}

Table 1: 96 hours acute toxicity test of Clariasgariepinus juveniles exposed to zinc.

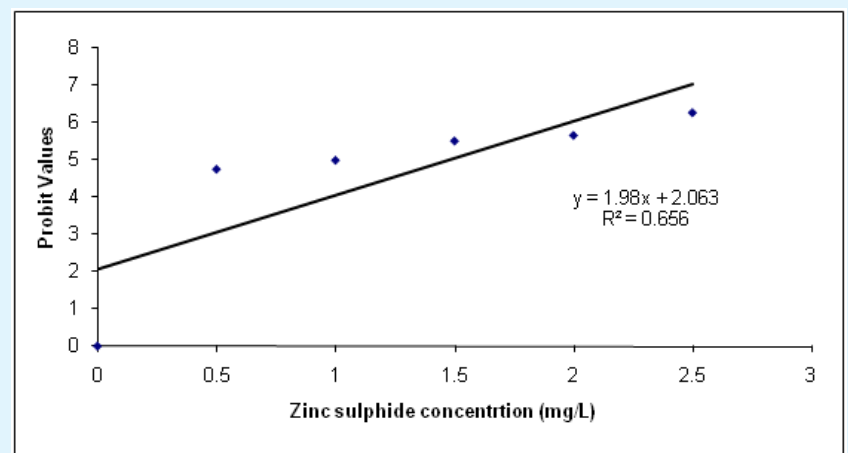

Figure 2: Regression of Probit mortality values and varied concentration of zinc sulphide exposed to juveniles of Synodontisclarias. 


\section{Advances in Clinical Toxicology}

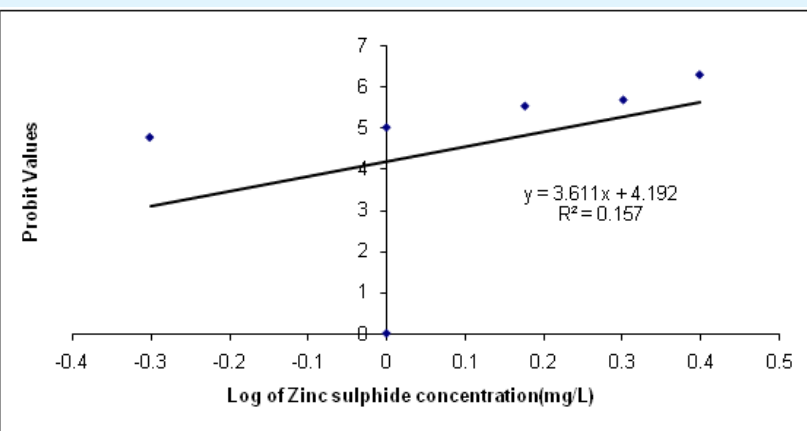

Figure 3: Regression of Probit mortality values and log of varied concentration of zinc sulphide exposed to juveniles of Synodontisclarias.

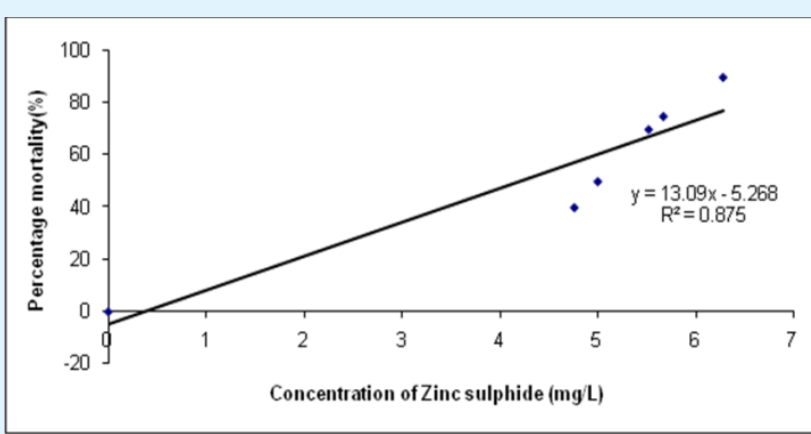

Figure 4: Regression of percentage mortality values and varied concentration of zinc sulphide exposed to juveniles of Synodontisclarias.

\begin{tabular}{|c|c|c|c|c|c|c|c|c|c|}
\hline \multicolumn{10}{|c|}{ Concentration of zinc sulphide in mg/L } \\
\hline $\mathbf{S} / \mathbf{n}$ & Parameters & $\mathbf{0}$ & $\mathbf{0 . 5}$ & $\mathbf{1}$ & $\mathbf{1 . 5}$ & $\mathbf{2}$ & $\mathbf{2 . 5}$ & mean & Std.Dev \\
\hline 1 & $\mathrm{DO}(\mathrm{mg} / \mathrm{L})$ & 5.81 & 5.32 & 5.01 & 4.31 & 3.91 & 3.91 & 4.71 & 0.79 \\
\hline 2 & Conductivity $(\mu \mathrm{s} / \mathrm{cm})$ & 434 & 613.5 & 490.9 & 470.5 & 440.5 & 331 & 463.4 & 91.93 \\
\hline 3 & $\mathrm{TDS}(\mathrm{mg} / \mathrm{L})$ & 216.5 & 302.5 & 232.5 & 226 & 220.5 & 202 & 233.33 & 35.41 \\
\hline 4 & $\mathrm{pH}$ & 7.14 & 7.52 & 7.63 & 7.64 & 7.28 & 7.54 & 7.46 & 0.2 \\
\hline 5 & Temperature $\left({ }^{\circ} \mathrm{C}\right)$ & 25.05 & 25.05 & 25.1 & 25 & 25.15 & 25.15 & 25.08 & 0.6 \\
\hline
\end{tabular}

Table 2: Water quality characteristics at different concentrations of zinc sulphide

\section{Discussion}

During the course of this study the Synodontisclarias juveniles were exposed to different concentration of zinc sulphide for a period of 96 hours. The fish response to the different concentration of the toxicant by showing some behavioural and physical characteristics from normal body colour/shape to abnormal swimming and to death at some instances. These observations are similar to those observed in Indian major Carp exposed to the different concentration of zinc ranging from 0.02 to $0.06 \mathrm{mg} / \mathrm{L}$ for 96 hours [2]. The $\mathrm{LC}_{50}$ determined during this study was at $1.00 \mathrm{mg} / \mathrm{L}$ of zinc sulphide toxicant exposed to the juveniles of Synodontisclarias exposed to the varied concentrations for acute toxicity period of $96 \mathrm{~h}$. This result differs significantly from the report of an earlier study that reported $\mathrm{LC}_{50}$ concentration of $3.00 \mathrm{mg} / \mathrm{L}$ zinc chloride exposed to red Tilapia, Oreochromis niloticus for $96 \mathrm{hrs}$ [17]. The difference in the $\mathrm{LC}_{50}$ concentration of the $\mathrm{Zn}$ for the same period of exposure may be due to the different fish species and toxicants. The toxicity of the zinc salts is different with different degree of toxicity and the different fish species may respond differently to the different zinc salts based on their tolerance ability of poisonous materials which is inherent in the different species of the fish. However, zinc concentration in the low range of 0.02 to $0.06 \mathrm{mg} / \mathrm{L}$ exposed to Indian Major Carp did not record any mortality during the acute exposure period [2]. Similarly, the findings of this present investigation differ significantly from those of Tian, et al., who did not report any death of Sea cucumbers (Apostichopusjapnicus) exposed to $1.00 \mathrm{mg} / \mathrm{L}$ of $\mathrm{ZnSO}_{4}$ [18]. $7 \mathrm{H}_{2} \mathrm{O}$ for $96 \mathrm{hrs}$ during their study period. This could be attributed to the fact that $\mathrm{ZnS}$ used in this study is more toxic or the fish is less tolerant to the toxicant during the exposure period. The fish species respond differently to different zinc salts and consequently the biology and fish physiology of the fish may also differ. More so, different toxicants have different toxic ability and hence their effect to the organisms when exposed to at different concentrations as observed in the course of this present study differs as well. In some case the short period of exposure may also a hindrance to the death of the fish to its high ability to detoxify the toxicant in its body system.

In this present study the variation in the water quality results due to application of the toxicant conforms to the findings of Rani et al ., [2] that observed a change in the water quality in the bowls applied with the toxicant when 


\section{Advances in Clinical Toxicology}

the fish is exposed to. Similarly, Hoq and Haque [19] reported change in the water quality parameters of the zinc metal at varied concentration exposed to the fresh water fish. The above findings conform to the result of this study. Ekwu, et al., reported a similar change in the water quality parameters at varied zinc concentrations when they exposed their fish during their study time [20]. This change may be due to the effect of the toxicant on the water quality parameters at varied concentrations in which the fish is exposed to and the time of the exposure International Association of Impact Assessment, IAIA [21].

\section{Conclusion}

The finding of this study showed that zinc sulphide is toxic is a toxic salt at elevated concentrations and have a relationship with the mortality of Synodontisclarias when exposed to it. This is evident in the effect in the conspicuous change in the water quality parameters and death of the fish at concentration as low as $1.0 \mathrm{mmg} / \mathrm{L}$, where half of the individuals of the fish exposed for 96 hours died.

\section{References}

1. Federal Research Progress Data base, FEDRIP (2004) Zinc Potential for Human Exposure. Federal Research data base, FEDRIP Bulletin 139-189.

2. Rani S, Kumar R, Yadav J (2017) Heavy metal induced alterations in acetlycholinesterase Activity of India major carps. Journal of Entomology and Zoology Studies 5(4): 818-821.

3. Shah AI (2017) Heavy metal impact on aquatic life and human health an overview.

4. Nnabo PO (2016) Surface water contamination of heavy metals from Enyigba $\mathrm{Pb}-\mathrm{Zn}$ mine District South eastern Nigeria, using metal enrichment and pollution indices. International Journal of Science and Technology 5(1): 8-18.

5. Mercy B, Dhanalakshmi B (2017) Toxicological Evaluation of heavy metals in tissues of Fresh water fish, Oreochromis niloticus collected from Lakes of Coimbatore District, Taminadu, India. International Research Journal of Pharmacy 8(1): 41-45.

6. FAO: Food and Agricultural Organisation (2007) The state of World Fisheries and Aquaculture. Food and Agriculture of the United Nations, pp: 162.
7. Akinsanya B, Hassan AA, Adeogun AO (2008) Gastro intestinal helminthes parasites of the fish Synodontisclarias (Siluriformes: Mochokidae) from Lekki Lagoon Lagos, Nigeria. Rev Biol Trop 56(4): 2021-2026.

8. Shinkafin BA, Argungu LA, Akabi HS (2010) Food and feeding habits (Syndonti Nigrita, Cuver and Valenciennes) in river Rima, Sokoto Nigeria. Nigerian Journal of Basic and Applied Science 18(2): 304-307.

9. Riede K (2004) Global register of Migratory Species from Global to Regional Scales. Final Report of R and D-project 80805081, Federal Agency for Nature Conservation, Boon Germany, pp: 329.

10. Ayoade JO (1983) Introduction to climatology for the tropics. Ibadan, Spectrum Books, pp: 179-184.

11. Abah RC (2012) Causes of seasonal flooding in flood plains a case of Makurdi, Northern Nigeria. International Journal of Environmental Studies 69(6): 904-912.

12. Ologunorisa ET, Tor T (2006) The Changing Rainfall Pattern and Its Implication for Flood Frequency in Makurdi, Northern Nigeria. Journal of Applied Science and Environmental Management 10 (3): 97 -102.

13. Federal Republic of Nigeria Official Gazetta (2007) The breakdown of the national and state provisional population totals of 2006 National census. The Federal Republic of Nigeria Official Gazetta, 94. Federal Government printer Lagos Nigeria, P B182.

14. Meyers MS, Johnson LL, Olson OP (1998) Histopathological hepatic lesions as biomarkers of chemical contaminants exposure and effects in marine bottom fish species from the north eastern and pacific coast, USA. Mar Pollut Bull. 37: 92-113.

15. Reish DL, Oshida PS (1987) Mannual of Methods in Aquatic Environmental Research. Part 1-10, Short term bioassays. FAO Tech 247: 1-62.

16. Finney DJ (1971) Probit Analysis 3 $3^{\text {rd }}$ ed. Cambridge University Press Cambridge 20pp 60(9): 1432.

17. Aldoghachi MA, Rahaman MM, Yusoff I, SofianAzrurun M (2016) Acute toxicity and bioaccumulation of heavy metals in red Tilapia fish. The Journal of Animal and Plant Science 26(2): 507513. 
18. Tian LX., Yu X, Dong S (2016) Effect of acute and chronic metal (Cu, $\mathrm{Cd}$ and $\mathrm{Zn}$ ) exposure to sea cucumbers (Apostichopus japonicus). Biomed Research International 1-13.

19. Hoq T, Haque N (2014) Effects of sublethal concentration of Zinc (II) Sulphate Heptahydrate $\left(\mathrm{ZnSO}_{4} .7 \mathrm{H}_{2} \mathrm{O}\right)$ on blood glucose of fresh water fish, Heteropneusters fossils. International Journal of Scientific and Technology 3(5): 128-131.
20. Ekwu AO, Oti EE, Undeh GN (2013) Effects of zinc on the distribution of major cations and anions in Clariasgariepinus from Ebonyi, river, Southeast Nigeria. Nigerian Journal of Fisheries 10( 1\&2) 599605.

21. International Association of Impact Assessment, IAIA conferencing proceeding 37th annual conference of the International Association of Impact Assessment, Le Centre Sheraton, Montreal, Canada: 1-7. 